\title{
СЛОВНИК ФРАЗЕОЛОГІЗМІВ УКРАЇНСБКОЇ МОВИ НА ПОЗНАЧЕННЯ НЕВЕРБАЛЬНОЇ КОМУНІКАЦЇ̈: ЗАСАДИ І ПРИНЦИПИ ПОБУДОВИ
}

\author{
Ганна Демиденко
}

\author{
Криворізький державний педагогічний університет \\ Kryvyi Rih State Pedagogical University \\ nр. Гагаріна, 54, Кривий Ріг, 50086, Украӥна \\ demidenko_anna@ukr.net
}

Демиденко Г. Словник фразеологізмів української мови на позначення невербальної комунікації: засади і принципи побудови

Статтю присвячено розгляду структури, змісту, особливостей побудови українського фразеологічного словника, який репрезентує невербальну комунікацію лінгвоносіїв; окреслено основні засади і принципи укладання лексикографічної праці, зокрема 3'ясовано специфіку словника за типом i призначенням, за характером репрезентації мовної одиниці, способом іiі подання; визначено орієнтовний обсяг реєстру фразем, загальну концепцію подачі матеріалу у словниковій статті. Проект словника, що транслює ментальну, етнічну своєрідність українців крізь призму невербального спілкування, є першою спробою упорядкування відповідних фразеологічних номінацій жестів, міміки, поз, ходи, комунікативно значущих рухів тощо.

Ключові слова: фразеологізм, невербальна поведінка, жест, міміка, словник, фразеографія.

Демиденко А. Словарь фразеологизмов украинского языка, определяющих невербальную коммуникацию: основы и принципы построение

Статья посвящена рассмотрению структуры, содержания, особенностей построения украинского фразеологического словаря, который показывает невербальную коммуникацию носителей языка; выясняются основы и принципы составления лексикографического труда, в том числе показана специфика словаря по типу и предназначению, по характеру представления языковой единицы, по способу ее подачи; определяется приблизительный объем реестра фразеологизмов, общая концепция предоставления материала в словарной статье. Проект словаря, который транслирует ментальное, этническое своеобразие украинцев сквозь призму невербального общения, является первой попыткой определенным образом упорядочить фразеологические номинации жестов, мимики, поз, походки, коммуникативно значимых движений и т. д.

Ключевые слова: фразеологизм, невербальное поведение, жест, мимика, словарь, фразеография.

-9- Г. Демиденко, 2019. 
Demydenko G. Dictionary of Ukrainian phraseologisms defying non-verbal communication: construction principles and fundamentals

The article focuses on the structure, content, peculiarities of constructing the dictionary of Ukrainian phraseologisms, which represent the non-verbal communication of speakers. It also outlines the basic principles and fundamentals of making lexicographic works. In particular, this paper represents the dictionary specifics in terms of the type and purpose, the way of the language unit representation, the approximate list of the fixed phraseological units, the general concept of the presenting the material in the dictionary article.

A dictionary project transfers the mental and ethnic identity of Ukrainians through the prism of non-verbal communication. This is the first attempt to register the phraseological units identifying gestures, facial expressions, poses, moves, communicatively meaningful movements, etc. The paper gives reviews of the basic principles of national and foreign dictionary writing, the principles of lexicography, which include the continuity of lexicographic works, the role of the subjective factor in the process of creating a dictionary, the selection of language units, and the pragmatism of similar research works. Particular attention is paid to the principle of anthropocentrism, which is implemented in the way of multiple registering the material, taking into account the information of different branches of science (linguistics, psychology, cultural studies, ethics, non-verbal semiotics, etc.). According to the principles of dictionary creating, its main tasks, the purposes of creation, lexicographic functions are identified. Moreover the paper determines the addressee of the phraseological work, who can use the information contained therein, according to the research needs nvestigating the Ukrainian communicative space, culture, traditions, national character and world outlook, etc.

The methodological fundamentals of the dictionary comprise the connection of modern phraseological studies with lexicographic traditions. As a result the reasons for listing the language units into the dictionary article are implemented due to the interpretation of the "phraseologism" term, represented in Ukrainian academic works studying phraseology problems. The analysis of researching papers allows enumerating the advantages of this dictionary type, which include actual information from other Eastern Slavic languages, encyclopaedic information, illustrations that enable the future reader to find out the cultural, linguistic and ethnographic aspects of Ukrainian phraseology.

Key words: phraseologism, non-verbal behavior, gesture, facial expressions, dictionary, phraseology.

\section{Постановка проблеми та їі зв'язок із важливими науковими завданнями. Упорядкування українського фразеологічного багатства на сучасному етапі розвитку лінгвістичної науки викликає посилений інтерес мовознавців у зв'язку із пошуками у фразеологічному значенні глибинних пластів ментальності народу, його лінгвосамобутності, особливостями сприйняття світу, ставлення до нього тощо.}


Новітня лексикографічна практика має у своєму складі чималу кількість фразеологічних словників: тлумачні, перекладні, словники говірок, словники-довідники, що, відповідно, сприяє розв'язанню й обгрунтуванню низки теоретичних i практичних питань мовознавчої науки. Однак нині перед укладачами подібних праць стоїть надскладне завдання, яке полягає в систематизації фразеологічного матеріалу відповідно до “ступеня розробки загальної фразеологічної теорії, від конкретних досліджень запасу літературної, ареальної, субстандартної ідіоматики, зіставнотипологічних студій” [Uzhchenko / Ужченко 2007 : 429].

Одним iз пріоритетних напрямків розвитку гуманітаристики загалом $€$ пошук шляхів реалізації мовної системи у взаємозв' язку із суспільством, яке потребує знань про себе, відображених у мові, і відтак вирішення проблеми мовної освіченості, компетенції представників певної нації. Відображення в мовній свідомості українців образів й уявлень про комунікативно значущі рухи тіла, які демонструють емоційних стан комунікаторів, їх культурно-етичний рівень, традиції чи ритуали, особистісні звички та ін., надає відомості про взаємозв'язок тілесного й емоційного життя лінгвоносіїв, спонукає до комплексного аналізу. За таких умов створення словника, який так чи так репрезентуватиме фразеологічний фонд української мови на позначення невербального спілкування, сприятиме розширенню комунікативного досвіду носія мови. Отже, як нам видається, адресат подібної фразеографічної праці може послуговуватися розміщеною в ній інформації з урахуванням потреб наукового й інтелектуального пізнання українського комунікативного простору, культури, традицій, національного характеру і світогляду тощо.

Аналіз останніх досліджень та публікацій. Невербальна комунікація українців досі не отримала свого лексикографічного опрацювання, що, відповідно, ускладнює й фразеологічні дослідження. У слов'янській лексикографічній практиці наявні певні надбання в напрямку вивчення невербальних одиниць, що презентують словники жестів і міміки [Akishyna / Акишина 1991; Grigorieva / Григорьева 2001]. Світовий досвід невербального 
словникарства, як слушно зазначає Т. Осіпова, передовсім спрямований на практику використання жестів у повсякденному житті й опануванням рідної та іноземної мови, серед яких одна 3 останніх лексикографічних праць французького психолога Ж. Мессинжера, що є виданням науково-популярного характеру і має базовий потенціал для створення інших сучасних словників невербаліки [Osipova / Осіпова 2018 : 112].

Незважаючи на значну кількість спільних жестів у представників слов'янських лінгвокультур, варто зосередити науковий пошук на національно-культурну специфіку невербальної комунікації, яку можливо простежити через фразеологічний пласт мови. Таке практичне напрацювання сприятиме урізноманітненню фразеографії загалом i невербальній лексикографії зокрема.

Мета наукової розвідки: аналіз особливостей побудови, принципів укладання словника фразеологізмів української мови, що репрезентуватиме невербальну взаємодію лінгвоносіїв. Задля цього виконували такі завдання: визначити основні функції словника, його мету, загальні принципи укладання; схарактеризувати специфіку побудови словникової статті.

Виклад основного матеріалу дослідження. Створення лексикографічної праці, яка має репрезентувати систему українських невербальних символів, проаналізувати представлення дібраних сталих зворотів у сучасних фразеологічних словниках української мови, дає змогу повніше зафіксувати культурні орієнтири в омовленні паралінгвальної інформації про носія мови. Вивчення й систематизація фактичного матеріалу передбачає критичний аналіз цих лінгвоодиниць 3 урахуванням національної специфіки найменувань невербальних явищ. Різноманіття паралінгвальної системи дає нам підстави твердити про достатню складність і багатовимірність ії фразеологічного втілення.

Досвід теоретичної i практичної лексикографії дає підстави визначити основні принципи укладання словника паралінгвальних фразеологізмів, що, відповідно, передбачає урахування спадкоємності лексикографічних творів, ролі суб'єктивного чинника у процесі створення словника,

(с) Г. Демиденко, 2019. 
нормативності у відборі лінгвоодиниць, прагматизму подібних наукових праць [Dubichynskyi / Дубічинський 2011 : 5-7].
Особливу
увагу
варто
приділити
принципу

антропоцентризму [Kapranov / Капранов 2013], який, на нашу думку, реалізується в подачі реєстрового матеріалу багатоаспектно, з урахуванням надбань різних царин знань, якот: мовознавства, психології, культурології, етики, невербальної семіотики та ін. Згідно із принципами укладання словника можемо схарактеризувати його основні завдання, мету створення, лексикографічні функції.

Мета створення словника полягає в тому, щоб по-новому описати такі мовні явища, як фразеологізми на позначення невербальної комунікації людей, вивчити їх характеристики, виявити й продемонструвати закономірності вербального втілення тої чи тої жестової одиниці. Головні завдання словника: ознайомити сучасного читача із фразеологічним багатством української мови, підвищити рівень його комунікативної компетенції, зорієнтувати користувача у процесі добору певного мовного засобу для успішної комунікації, ураховуючи іiі невербальний рівень. Фразеографічна праця має проінформувати мовця про жести, міміку, пози, ходу, зорову комунікацію, які властиві українцям.

Як відомо, у будь-якій моделі словника мають бути реалізовані всі універсальні лексикографічні функції [Kapranov / Капранов 2013 : 47]. Однією 3 функцій, які має виконувати запропонований словник фразем, є інформаційна, що забезпечує, відповідно, його інформаційне наповнення і структуру. Важливим чинником при формуванні мовленнєвої компетенції адресата такої фразеографічної праці $\epsilon$ врахування труднощів, пов'язаних із використанням сталих зворотів і відсутності довідників про жестовий невербальний код українців, 3 яких читач може отримати потрібну йому інформацію. Окремої ваги набуває комунікативна функція словника - забезпечення членів суспільства мовними й немовними засобами спілкування, оскільки знання про невербальну поведінку сприяють витлумаченню більшості жестів із позиції їх нормативності, традиційності, доречності, вагомості та ін. за певних комунікативних ситуацій. 
Пропонований словник повинен успішно виконувати й інші функції, а саме: функцію реєстрування лінгвоодиниць та їх систематизації, що дають змогу вивчити мовні факти певного періоду, з'ясувати системні зв'язки. Системні відношення у фразеології на позначення невербальних явищ виразно ілюструє синонімія, сформована завдяки емоційній складовій фразеологічного значення. Як засвідчує аналіз, фраземи 3 невербальним компонентом вирізняються варіативністю компонентного складу, що забезпечується взаємозаміною невербальних знаків, грунтованих на рухах різних зон тіла, що тим не менш подають однакову інформацію про учасників узаємодії (наприклад, підняті брови та великі очі вказують на емоцію “здивування”) [Demydenko / Демиденко 2014 : 45].

На основі аналізу наукових джерел можемо виокремити переваги й достоїнства, словника зазначеного типу, що передбачає залучення фактичного матеріалу 3 інших східнослов'янських мов, використання енциклопедичних відомостей, ілюстрацій. Це дасть змогу майбутньому читачу 3'ясувати культурологічний та лінгвокраїнознавчий аспект української фразеології і тим самим забезпечує реалізацію пізнавальної та навчальної функції.

На окремий коментар заслуговує методологічне підгрунтя словника, яке передбачає зв'язок сучасних фразеологічних студій з лексикографічними традиціями, тому обгрунтування добору тих чи тих мовних одиниць у межах словникової статті спричинено витлумаченням поняття “фразеологізм” в українських академічних фразеографічних працях.

Відповідно до викладеного вище, можемо окреслити й узагальнити загальні риси словника, а саме:

1) за типом i призначенням - це тлумачний словник фразеологізмів української мови, основне завдання якого полягає не у звичайному витлумаченні мовного матеріалу, відтворенні вже відомої інформації, зафіксованої іншими фразеологічними словниками, а передусім у репрезентація лінгвокультурологічної інформації, закладеної в мовних знаках. Джерелом такої інформації $€$ закріплені в мовному соціумі знання про невербальні засоби спілкування, що позначають ці знаки;

() Г. Демиденко, 2019. 
2) за характером реєстрової одиниці - це словник усталених стійких словосполучень, де в основу розуміння фразеологічної одиниці покладено думку про те, що до фразем зараховуються лише сталі вислови 3 постійним, відтворюваним за традицією складом компонентів, у яких втрачена лексична самостійність і які виражають цілісне фразеологічне значення. За таких умов до словника не будуть вноситися прислів'я, приказки, порівняльні звороти, афоризми, перифрастичні звороти, термінологічні словосполучення тощо;

3) обсягом реєстру складає близько 2000 одиниць. Задля створення якнайповнішого реєстру ми намагалися відібрати лінгвоодиниці, які ілюстрували би невербальну поведінку українців, які були би різними за стилістичними і жанровими характеристиками, поширеністю (діалектні), вибравши їх 3 різних найбільш авторитетних джерел. Основне завдання: створити словник-довідник, що репрезентуватиме усталені вирази, які втілюють комунікативний досвід лінгвоносіїв;

4) за принципом добору реєстрових одиниць словник міститиме мовні одиниці, зафіксовані хоч би одним фразеологічним або тлумачним словником, зокрема в запланованій лексикографічній праці передбачено враховувати й регіональний аспект утілення невербального життя носіїв мови, а отже залучати фраземи з діалектних словників;

5) із культурологічної позиції словник міститиме певні культурологічні коментарі i, відповідно, до словникових статей за певних умов варто долучати мовні одиниці, дібрані 3 фразеографічних джерел інших мов (білоруська, російська);

6) принципом укладання реєстру фразем $є$ алфавітний принцип, який, зважаючи на невеликий обсяг словника, $€$ найзручнішим для користувача;

7) за способом впорядкування словникових статей передбачено використання ілюстративного матеріалу, енциклопедичну інформацію (якщо така є). У запланованому словнику вживання одиниць враховуватиме варіанти, а також факультативні компоненти структури, синонімічні одиниці, відповідні тлумачення невербальних одиниць (жестові, мімічні, пантомімічні), а також, як зазначалося, міжмовні паралелі 
(за умови фіксації таких ФО у фразеологічних словниках інших мов). За цим же принципом варто подавати й ілюстративний матеріал (приклади з художньої літератури, публіцистики);

8) 3 позиції адресата цей словник розрахований на широке коло читачів, які прагнуть більш глибоко вивчити фразеологічне багатство української мови й розширити уявлення про невербальну поведінку загалом.

Подаємо зразки словникових статей:

БИТИ СЕБЕ [КУЛАКОМ] В ГРУДИ - УжИваєТься в ситуаціях, коли мовець гаряче запевняє, переконує кого-небудь у чомусь. Вислів вербалізує відомий жест бити себе у груди, який має релігійне значення i виражає ідею покаяння. Спрямованість руху руки на груди пов'язана 3 тим, що саме на них знаходиться натільний хрест - традиційний сакральний предмет для клятви.

ХИЛИТИ (КЛОНИТИ) ГОЛОВУ - уживається в ситуаціях, коли людина виявляє покору перед ким-небудь, підкоряється комусь; висловлює свою пошану, повагу до кого-, чого-небудь; журиться, засмучується, перебуває у відчаї. Підгрунтям для утворення вислову послужив невербальний рух схилити голову, який ілюструє такий момент: жестикулянт стоячи схиляє голову й дивиться вниз; відповідна поза виражає скорботу та покору.

До деяких усталених виразів подаються синоніми - один чи кілька:

ОЧІ МЕТАЮТЬ ІСКРИ - уживаються задля вираження негативних почуттів (злості, гніву, незадоволення тощо). Такі вислови вказують на зорову комунікацію, демонструючи недоброзичливість погляду, що може виражатися у розмірі зіниць, широкому розкритті очей чи звуженні повік тощо. Синоніми: [ажс] іскри з очей сиплються (летять, скачуть); кресати очима; метати очима (з очей) іскри.

В окремих випадках, окрім синонімічних одиниць, пропонуюся фразеологізми з інших мов (білоруська, російська).

ПОСИЛАТИ БІСИКИ - вислів є характерними для такої поведінкової реакція як кокетство; він вказують на різне оцінне

() Г. Демиденко, 2019. 
ставлення до об'єкта симпатії. Синоніми: пускати бісики [очима (оком)]; пускати гудзики [очима (оком)]; пускати гедзики. Пор. рос.: строить [делать] глазки - кокетничать “игриво, кокетливо поглядывать на кого-либо, кокетничать с кем-либо".

ГНУТИСЯ (ЗГИНАТИСЯ) В ДУГУ (В ТРИ ПОГИБЕЛІ) - уживається зі значенням “плазувати, запобігати перед кимсь, виявляючи покірність”. ФО втратила зв’язок із відповідним пантомімічним жестом гнути спину і відтворює лише культурно-національні уявлення про поведінку покірної, улесливої людини. Пор.: білор.: гнуцца у тры пагібелі в таких значеннях - “1) вельмі нізка нахіляцца, згінацца; 2) перан. знач. празмерна ўгоднічаць".

Висновки та перспективи подальших наукових розвідок. Проект словника фразеологізмів української мови на позначення невербального спілкування має рекомендаційний характер й окреслює основні засади і принципи побудови подібної лексикографічної праці у вітчизняному мовознавстві. Запропонований словник сприятиме актуалізації досліджень у царині фразеології української мови, невербаліки, лінгвокультурології, етнопсихології, а також сприятиме розширенню фразеографічної теорії і практики. Фразеологічне багатство української мови, систематизоване й описане в подібній праці, поглибить знання носіїв мови щодо особливостей уживання тих чи тих лінгвоодиниць, реалізації в мові світоглядних стереотипів, норм спілкування, утілених у жестах, міміці, пантоміміці тощо. У зв'язку із цим, вважаємо, словник має вплинути на підвищення рівня мовної та комунікативної компетенції українців, посприяти зацікавленню у вивченні рідної мови та культурної спадщини, розробці ідей і концепцій дослідження невербальної комунікації в українському науковому просторі.

\section{Література}

1. Акишина А. А., Кано Х., Акишина Т. Е. Жесты и мимика в русской речи : Лингвострановедческий словарь. Москва : Русский язык, 1991. 146 с.

2. Григорьева С. А., Григорьев Н. В., Крейдлин Г. Е. Словарь языка русских жестов. Москва-Вена: Языки русской культуры ; Венский славистический альманах, 2001. 256 с. 
3. Демиденко Г. Паралінгвальні фразеологізми в українській етнокультурі : монографія. Кривий Ріг : НПП Астерікс, 2014. 175 с.

4. Дубічинський В. В. Лексикографія : навч.-метод. посіб. Харків : НТУ "ХПІ", 2011. $66 \mathrm{c.}$

5. Капранов Я. В. Принципи узагальнення словникових відомостей як моделювання плану змісту мови. Вісник КНУЛ. Серія Філологія. Том 16. № 1. 2013. C. $46-52$.

6. Лепешаў І. Я. Фразеалагічны слоўнік беларускай мовы : у 2-х т. Мінськ : Беларуская энцыклапедыя імя П. Броўкі, 2008. Т. 1. 672 с. ; Т. 2.704 с.

7. Осіпова Т. Ф. Невербальні засоби комунікації: комплексна методика опису й лексикографування. Studia Ukrainica Posnaniensia. 2018. Vol. VI. P. $107-113$.

8. Словник фразеологізмів української мови / уклад. В. М. Білоноженко та ін. Київ : Наук. думка, 2003. 1104 с.

9. Ужченко В. Д., Ужченко Д. В. Фразеологія сучасної української мови : навч. посіб. Київ : Знання, 2007. 494 с.

10. Фразеологический словарь русского языка [свыше 4000 слов. статей] / под ред. А. И. Молоткова. 2-е изд., стереот. Москва : Советская эн-дия, 1968. $543 \mathrm{c}$.

\section{References}

1. Akishyna A. A., Kano Kh., Akishyna T. Ye. Zhesty i mimika v russkoi rechi : Linhvostranovedcheskiy slovar. Moskva : Russkyi yazyk, 1991. 146 s.;

2. Grigorieva S. A., Grigoriev N. V., Kreidlin G. Ye. Slovar yazyka russkih zhestov. Moskva-Vena : Yazyki russkoi kultury ; Venskiy slavisticheskiy almanah, 2001. $256 \mathrm{~s}$.

3. Demydenko H. Paralinhvalni frazeolohizmy $\mathrm{v}$ ukrainskii etnokulturi : monohrafiia. Kryvyi Rih : NPP Asteriks, 2014. $175 \mathrm{~s}$.

4. Dubichynskyi V. V. Leksykohrafiia : navch.-metod. posib. Kharkiv : NTU "KhPI", 2011. $66 \mathrm{~s}$.

5. Kapranov Ya. V. Pryntsypy uzahalnennia slovnykovyh vidomostei yak modeliuvannia planu zmistu movy. Visnyk KNUL. Seriia Filolohiia. Tom 16. № 1. 2013. S. 46-52.

6. Lepeshav I. Ya. Frazealahichny slovnik belaruskai movy : u $2 \mathrm{kh}$ t. Minsk : Belaruskaia entsyklapedyia imia P. Brovki, 2008. T. 1., 672 s. ; T. 2, 704 s.

7. Osipova T. F. Neverbalni zasoby komunikatsii: kompleksna metodyka opysu y leksykohrafuvannia. Studia Ukrainica Posnaniensia. 2018. Vol. VI. P. 107-113.

8. Slovnyk frazeolohizmiv ukrainskoi movy / uklad. V. M. Bilonozhenko ta in. Kyiv : Nauk. dumka, 2003. $1104 \mathrm{~s}$.

9. Uzhchenko V. D., Uzhchenko D. V. Frazeolohiia suchasnoi ukrainskoi movy : navch. posib. Kyiv : Znannia, 2007. $494 \mathrm{~s}$.

10. Frazeologicheskyi slovar russkogo yazyka [svyshe 4000 slov. statei] / pod red. A. I. Molotkova. 2-e yzd., stereot. Moskva : Sovetskaia en-diia, 1968. 543 s.

\section{Стаття надійшла до редакиії 07.03.2019 p. Прийнята до друку 07.05.2019 p.}

